Abstracta Iranica Abstracta Iranica

Revue bibliographique pour le domaine irano-aryen

Volume 26 | 2005

Comptes rendus des publications de 2003

Pažūheš-hā-ye zabān-šenāsī-e īrānī (1). Jašn-nāme-ye doktor 'Alī-Ašraf Șādeqī. Omīd Ṭabībzāde, éd., Tehrān, Hermes, 1382/2003, 408 p.

Charles-Henri de Fouchécour

(2) OpenEdition

Journals

Édition électronique

URL : http://journals.openedition.org/abstractairanica/3724

ISSN : 1961-960X

Éditeur :

CNRS (UMR 7528 Mondes iraniens et indiens), Éditions de l'IFRI

Édition imprimée

Date de publication : 15 mai 2005

ISSN : 0240-8910

Référence électronique

Charles-Henri de Fouchécour, «Pažūheš-hā-ye zabān-šenāsī-e îrānī (1). Jašn-nāme-ye doktor 'Alī-Ašraf Șādeqī. Omīd Tạīizzāde, éd., Tehrān, Hermes, 1382/2003, 408 p. », Abstracta Iranica [En ligne], Volume 26 | 2005, document 52, mis en ligne le 08 décembre 2005, consulté le 25 septembre 2020. URL :

http://journals.openedition.org/abstractairanica/3724

Ce document a été généré automatiquement le 25 septembre 2020.

Tous droits réservés 


\title{
Pažūheš-hā-ye zabān-šenāsī-e īrānī (1). Jašn-nāme-ye doktor (Alī-Ašraf Șādeqī. Omīd Ṭabībzāde, éd., Tehrān, Hermes, 1382/2003, 408 p.
}

\author{
Charles-Henri de Fouchécour
}

On trouvera un c.r. de l'ouvrage par Moḥammad RāseH Mehand dans Našr-e Dāneš, 20, 2 (1382/2003), pp. 59-61. Ce premier volume d'une collection consacrée à la linguistique iranienne, est constitué principalement d'un entretien important avec 'Alī-Ašraf Șādeqī, membre de l'Académie. Le savant linguiste fait un tour d'horizon de son domaine du persan. Huit chapitres y font suite, sur des sujets variés, principalement d'ordre grammatical. Le projet est de publier par la suite des volumes à thème. Une publication prometteuse.

\section{INDEX}

Thèmes : 2.2. Langues vivantes et dialectes

Mots-clés : linguistique, langue persane

Keywords : linguistics, Persian language 


\section{AUTEURS}

\section{CHARLES-HENRI DE FOUCHÉCOUR}

Fondateur de la revue Abstracta Iranica - Paris 